\title{
Clearly Erroneous Review of Mixed Questions of Law and Fact: The Likelihood of Confusion Determination in Trademark Law
}

\author{
Patricia J. Kaeding $\dagger$
}

The key issue in a trademark infringement case is whether the contested mark creates a likelihood of confusion with a previously used or registered mark. ${ }^{1}$ The federal courts of appeals generally agree on the factors to be considered in determining. whether a likelihood of confusion exists. The appellate courts disagree, however, on whether a lower court's determination of the likelihood of confusion should be treated as a question of fact, upheld unless clearly erroneous, or as a question of law, reviewable de novo.

The Second, Sixth, and Federal Circuits view the issue as a mixed question of law and fact. They treat the determination of the likelihood of confusion as a question of law reviewable de novo, while according clearly erroneous review to the specific findings on which the determination was based. ${ }^{2}$ The Ninth Circuit also defines likelihood of confusion as a mixed question of law and fact but accords clearly erroneous review to all aspects of the inquiry. ${ }^{3}$ The remaining circuits define the likelihood of confusion inquiry as a question of pure fact subject to clearly erroneous review. ${ }^{4}$

† B.A. 1989, University of Wisconsin, Madison; J.D. 1992, The University of Chicago.

' See Fleischmann Distilling Corp. v Maier Brewing Co., 314 F2d 149 (9th Cir 1963). As defined by the Lanham Act, 15 USC § 1127 (1992):

[t]he term 'trademark' includes any word, name, symbol, or device or any combination thereof-(1) used by a person, or (2) which a person has a bona fide intention to use in commerce and applies to register on the principle register established by this Act, to identify and distinguish his or her goods, including a unique product, from those manufactured or sold by others and to indicate the source of goods, even if that source is unknown.

The Lanham Act protects "marks," which "includes any trademark, service mark, collective mark, or certification mark." Id. In this Comment, the terms "mark" and "trademark" encompass the marks protected by the Lanham Act, 15 USC $\$ 1114$ (1) (1992), and false designations of origin prohibited by the Lanham Act, 15 USC $\$ 1125$ (a) (1992).

${ }^{2}$ See notes 52-63 and accompanying text.

${ }^{3}$ See notes $46-51$ and accompanying text.

- See notes 36-37, 40-45 and accompanying text. 
This Comment argues that likelihood of confusion is a mixed question of law and fact that should be treated as a factual issue for review purposes. The trial court, as fact finder, is best situated to determine the likelihood of confusion issue, the crucial question in a trademark infringment case. Thus, appellate courts should review likelihood of confusion determinations under a clearly erroneous standard. Section I explores the fact-driven nature of the inquiry by examining the factors and evidence courts use to determine likelihood of confusion issues. Section II analyzes existing review standards and the rationales for these standards. Section III explains why the likelihood of confusion inquiry is a mixed question of law and fact and discusses the difficulties courts have in determining the review standard appropriate for a mixed question. This Section also considers the problems that result from the absence of a uniform review standard. Section IV concludes that treating likelihood of confusion as a factual issue for review purposes is consistent with Supreme Court jurisprudence, and finds support in the treatment of two analogous determinations in other areas of law. Adoption of a uniform review standard will promote judicial accuracy and efficiency, discourage forum shopping, and end the confusion over likelihood of confusion.

\section{The LiKelihood of CONFusion INQUIRY}

As part of the law of unfair competition, trademark infringement is a business tort..$^{5}$ Because trademarks assist consumers in identifying products and allow producers to control the reputation of their products, trademarks are assets, part of a business's goodwill. ${ }^{6}$ The first producer to adopt a mark that distinguishes its products from another producer's has a legally enforceable right to that mark's exclusive use. ${ }^{7}$ To prevail on an infringement claim, a plaintiff must establish that its mark distinguishes its product from that of another, and that the defendant's mark is likely to cause confusion. ${ }^{8}$ Likelihood of confusion is the test of infringment

\footnotetext{
- See Keebler Co. v Rovira Biscuit Corp., 624 F2d 366, 372 (1st Cir 1980). See also United Drug v Rectanus Co., 248 US 90, 97 (1918). The tort is based on the premise "that one merchant shall not divert customers from another by representing what he sells as emanating from the second." Yale Electric Corp. v Robertson, 26 F2d 972, 973 (2d Cir 1928).

- See Scandia Down Corp. v Euroquilt, Inc., 772 F2d 1423, 1429-30 (7th Cir 1985).

7 See United Drug, 248 US at 100 . The party seeking damages, usually the senior user of the mark, has standing to sue because the senior user has "quasi-property rights" in the mark. See Bonito Boats v Thunder Craft Boats, 489 US 141, 157 (1989).

${ }^{s}$ See 15 USC $\$ \S 1114(1), 1125(a)$.
} 
(1) in federal court actions involving federally registered marks ${ }^{9}$ and unregistered marks and trade dress protectable under the Lanham Act; ${ }^{10}$ (2) in state court actions involving marks or trade dress protectable at state common law and marks registered with state authorities; and (3) by the Patent and Trademark Office in registration-related proceedings. ${ }^{11}$

\section{A. The Ordinarily Prudent Purchaser Standard}

Likelihood of confusion exists when "an appreciable number of ordinarily prudent purchasers are likely to be misled, or indeed simply confused, as to the source of the goods in question."12 The word "likely" is key; a party must establish that consumer confusion is probable, not inevitable. ${ }^{13}$ The trier of fact should inquire whether ordinary consumers, buying with ordinary caution, are likely to be misled in their general recollection of the marks, ${ }^{14}$ not whether the marks are similar when compared side-by-side. In other words, "the marks must be compared in the light of what occurs in the marketplace, not in the courtroom."15

\section{B. Evidentiary Factors Used in Determining Likelihood of Confusion}

Because more than the marks themselves are relevant to likelihood of confusion determinations, courts look to a number of other considerations. ${ }^{16}$ Although each circuit has its own variant of the

- 15 USC \& 1114(1)(a). See also Fleischmann, 314 F2d at 151-52.

10 15 USC $\$ 1125$ (a). See also Scandia Down, 772 F2d at 1423 (applies test to unregistered mark). Trade dress refers to a product's packaging, labeling, or design, Stormy Clime

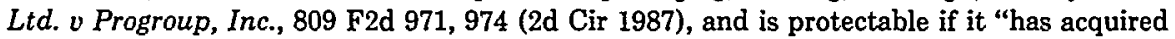
a secondary meaning by which it is identified with its producer or source." LeSportsac, Inc. v K Mart Corp., 754 F2d 71, 75 (2d Cir 1985).

11 I5 USC § 1052(d). The Patent and Trademark Office (PTO) may refuse to register a mark or may cancel the registration of a mark if likelihood of confusion exists with a previously registered or used mark. See 15 USC $\S \S 1063,1064$. PTO decisions on registration or cancellation can be appealed to the Trademark Trial and Appeal Board (TTAB), an administrative tribunal. TTAB decisions can be reviewed by appeal to the Federal Circuit or by a civil action in an appropriate United States District Court. 15 USC $\$ 1071$.

12 Perini Corp. $v$ Perini Construction, Inc., 915 F2d 121, 127 (4th Cir 1990), quoting Mushroom Makers, Inc. v R.G. Barry Corp., 580 F2d 44, 47 (2d Cir 1978).

${ }^{13}$ Eclipse Assoc., Ltd. v Data General Corp., 894 F2d 1114, 1118-19 (9th Cir 1990).

14 See Country Floors, Inc. v Gepner, 930 F2d 1056, 1064 (3d Cir 1991).

${ }^{25}$ Amoco Oil Company v Rainbow Snow, Inc., 809 F2d 656, 662 (10th Cir 1987).

${ }_{18}$ This Comment focuses on the kinds of trademark disputes that are likely to reach the appellate level. Usually, if a competitor uses a mark that is identical or nearly identical to a plaintiff's mark, "the court need rarely look beyond the mark itself. . . . the court will generally examine the registered mark ... and compare it against the challenged mark." 
precise set of factors the trier of fact should consider, ${ }^{17}$ these lists all derive from the Restatement of Torts. ${ }^{18}$

The factors generally include, at a minimum: (1) the similarity of the marks; ${ }^{19}$ (2) similarities between the goods or services; (3) the likely degree of purchaser care; (4) the strength of the plaintiff's mark in the marketplace; ${ }^{20}$ (5) the defendant's intent; and (6) incidents of actual confusion. Depending on the case and the circuit, these evidentiary factors may also include: the degree to which the products share common purchasers; similarities between the parties' advertising and marketing channels; and, if the goods are related but do not directly compete with one another, the likelihood that the senior user will expand so as to compete directly

Interpace Corp. v Lapp, Inc., 721 F2d 460, 462 (3d Cir 1983). Such “open and shut" cases do not involve lengthy litigation to determine liability and rarely, if ever, reach the appeals courts. See Opticians Association of America $v$ Independent Opticians of America, 920 F2d 187, 195 (3d Cir 1990). Thus, the following discussion of evidentiary factors and their use applies, for example, to disputes over marks on used goods that do not directly compete with one another or marks that are similar but not identical.

17 See, for example, Polaroid Corp. $v$ Polarad Electronics Corp., 287 F2d 492, 495 (2d Cir 1961); Giant Food, Inc. $v$ Nation's Foodservice, Inc., 710 F2d 1565, 1569-71 (Fed Cir 1983).

${ }^{18}$ See Restatement of Torts $\S \S 729,731$ (1939). The Restatement articulates a set of factors for infringement claims involving marks used on directly competing goods in $\S 729$, and a more elaborate set of factors for use in the context of infringement claims concerning marks used on goods that are related, but do not directly compete with one another in $\S 731$. However, courts tend to overlook this distinction and use one set of evidentiary factors for both types of claims. See, for example, Charles of the Ritz Group $v$ Quality King Distributors, 832 F2d 1317, 1318, 1321-23 (2d Cir 1987). The Restatement (Second) omits all sections on unfair competition. The ALI council decided that it is no longer appropriate to include the area in the Restatement of Torts since unfair competition is largely an independent body of law. 8 Restatement (Second) of Torts 1-2 (1979).

10 To make a finding on this issue, a court may consider the degree of similarity between the designation and the trademark or trade name in (a) appearance, (b) pronunciation of the words used, (c) verbal translation of the pictures or designs involved, and (d) suggestion. Restatement of Torts $\$ 729$. But in doing so, "a court must.look to the overall impression created by the marks and not merely compare individual features." General Mills, Inc. $v$ Kellogg Co., 824 F2d 622, 627 (8th Cir 1987).

20 A trier of fact will first consider the degree to which the mark is distinctive. A mark consisting of a fanciful term (for example, KODAK) is inherently distinctive and is presumed to be strong within the relevant market. However, if the mark is a descriptive term (for example, AUTO PAGE) a trier of fact must determine whether it has acquired distinctiveness or, secondary meaning, through use. 15 USC $\$ 1052(f)$. A mark consisting of a suggestive term (for example, TIDE) hints at a characteristic of the good and requires the consumer to use some degree of imagination to determine the good's nature. A trier of fact must determine, however, whether the mark is truly suggestive or whether it is descriptive and requires proof of secondary meaning. See G. Heileman Brewing Co. $v$ Anheuser-Busch, Inc., 873 F2d 985, 991-92 (7th Cir 1989). A mark's strength may be increased by "extensive advertising, length of time in the market, public recognition, and uniqueness." Century 21 Real Estate Corp. v Sandlin, 846 F2d 1175, 1179 (9th Cir 1988). 
with the alleged infringer. ${ }^{21}$ Regardless of the formulation used, the factors "imply no mathematical precision," and a plaintiff need not prevail on all, or even most, of the factors to prevail overall. ${ }^{22}$

C. The Use of Law and Fact in the Judicial Determination of Likelihood of Confusion

Although a court's finding on the similarity of two marks may be based on a subjective judgment, the inquiries into factors other than similarity entail objective fact-finding that can be supported by evidence. Judicial findings on these factors can draw inferences from testimonial, documentary, and survey evidence, as well as exhibits, expert witnesses, and other sources. ${ }^{23}$ For example, to determine a mark's strength, a court might consider evidence detailing the use of the mark, including sales and advertising information and testimony from representative consumers. ${ }^{24}$ Similarly, to determine or infer a defendant's intent in selecting a mark, courts may use evidence concerning the process by which the mark was selected and the defendant's knowledge of the plaintiff's mark. ${ }^{25}$

To establish actual confusion, a plaintiff may introduce communications suggesting confusion, such as records of telephone conversations, mail received, and inquiries of retailers and consumers. ${ }^{26} \mathrm{~A}$ plaintiff may also present oral testimony of actual confusion. $^{27}$ In addition, litigants are increasingly using market research-reaction tests or surveys indicating the response of a

\footnotetext{
${ }^{21}$ See Yale Electric Corp. $v$ Robertson, 26 F2d 972, 973-74 (2d Cir 1928) (YALE flashlights and batteries create a likelihood of confusion with YALE locks).

${ }^{22}$ See Wynn Oil Co. v Thomas, 839 F2d 1183, 1186 (6th Cir 1988). A number of appellate courts require the trial court to consider all of the circuit's factors before denying or, in some cases, awarding a plaintiff relief. See, for example, Volkswagenwerk $v$ Wheeler, 814 F2d 812, 817 (1st Cir 1987); Sun-Fun Products v Suntan Research \& Development, 656 F2d 186, 189 (5th Cir 1981). The Eleventh Circuit expects the lower court to consider all the factors "relevant" to the dispute. Wesco Mfg., Inc. v Tropical Attractions of Palm Beach, Inc., 833 F2d 1484, 1489 (11th Cir 1987). However, the Ninth and Second Circuits do not require the lower court to review a specific list of factors in every case. See Eclipse Assoc., 894 F2d at 1118; Orient Express Trading Co. v Federated Dept. Stores, Inc., 842 F2d 650, 654 (2d Cir 1988).

${ }^{23}$ See Rudolf Callmann, 3A The Law of Unfair Competition Trademarks and Monopolies $\$ \S 20.63,20.63 .05$ (Callaghan 1988).

24 See Dieter v $B \& H$ Industries of Southwest Florida, 880 F2d 322, 326-27 (11th Cir 1989).

${ }^{25}$ See Sands, Taylor \& Wood v The Quaker Oats Co., 18 USPQ2d 1457, 1471-72 (N D Ill 1990).

${ }^{28}$ See International Kennel Club v Mighty Star, Inc., 846 F2d 1079, 1082 (7th Cir 1988).

${ }^{27}$ See Jockey International, Inc. v Burkard, 185 USPQ 201, 205 (S D Cal 1975).
} 
relevant group of consumers to a particular mark-to demonstrate the existence or absence of a likelihood of confusion..$^{28}$

A likelihood of confusion determination requires a court to consider whether the "totality of circumstances," the findings on the evidentiary factors, ${ }^{30}$ meets the legal standard of whether potential purchasers of the product are likely to be confused. To reach a conclusion, a trier of fact, using the ordinary purchaser construct as a guide, weighs and balances the findings in accordance with the circumstances of the particular infringement and the context of the mark's use.

\section{Existing Standards of Review}

Justice White has noted that the federal circuit courts have split over the question of "whether a district court's finding of a likelihood of confusion in a trademark infringement matter under [the Lanham Act] is reviewable under the 'clearly erroneous' standard, as a finding of fact, or de novo, as a conclusion of law." 31 Federal Rule of Civil Procedure (FRCP) 52(a) mandates that findings of fact may be set aside only if they are clearly erroneous. ${ }^{32}$ Courts review conclusions of law de novo. Where, however, a determination is neither a question of pure fact ${ }^{33}$ nor clearly a question of law, ${ }^{34}$ an appellate court must decide whether to treat it as law 1987).

${ }^{28}$ See, for example, Mutual of Omaha Ins. Co. $v$ Novak, 836 F2d 397, 400-01 (8th Cir

28 Schwinn Bicycle Co. v Ross Bicycles, Inc., 870 F2d 1176, 1184 (7th Cir 1989).

${ }^{30}$ No single factor alone is determinative. Piper Aircraft Corp. $v$ Wag-Aero, Inc., 741 F2d 925, 934 (7th Cir 1984). The similarity of the marks, the defendant's intent, and actual confusion are frequently considered to be more important than the other factors. See Henri's Food Products Co. v Kraft, Inc., 717 F2d 352, 354 (7th Cir 1983). But neither wrongful intent nor evidence of actual confusion is necessary for likelihood of confusion to exist. Century 21, 846 F2d at 1178.

31 McMonagle v Northeast Women's Center, Inc., 493 US 901, 904 (1989) (White dissenting from denial of certiorari).

${ }^{32}$ The pertinent provision, FRCP 52(a), states: "Findings of fact, whether based on oral or documentary evidence, shall not be set aside unless clearly erroneous, and due regard shall be given to the opportunity of the trial court to judge the credibility of the witnesses."

${ }^{33}$ Questions of fact, often termed historical facts, generally encompass inquires about who, what; and where and can be made by persons ignorant of the applicable law. See Henry P. Monaghan, Constitutional Fact Review, 85 Colum L Rev 229, 235 (1985). A question of fact is "an issue involving the resolution of a factual dispute . . ." Black's Law Dictionary, 1246 (West, 6th ed 1990).

34 A question of law is "an issue which involves the application or interpretation of a law ...." Black's Law Dictionary at 1246. 
or fact for purposes of review. ${ }^{\text {s5 }}$ Disagreements over which standard of review applies to likelihood of confusion determinations arise because the inquiry implicates legal principles and is highly fact dependent.

\section{A. Clearly Erroneous Review}

The federal circuit courts that treat likelihood of confusion as a question of fact reverse a lower court's findings on any of the evidentiary factors and its ultimate determination of the likelihood of confusion only where they are clearly erroneous. ${ }^{36}$ Most of these appellate courts define likelihood of confusion as a question of pure fact. ${ }^{37}$ The Ninth Circuit, by contrast, defines likelihood of confusion as a mixed question of law and fact, but nevertheless treats it as a question of fact for review purposes, ${ }^{38}$ so that appellate review in the Ninth Circuit is the same as in the circuits that define the issue as a question of pure fact. The Ninth Circuit, however, has provided more explicit and thorough policy and analytical rationales for clearly erroneous review than have other circuits applying that standard. ${ }^{39}$

1. Justifications for classifying likelihood of confusion as a question of pure fact.

Nine circuits define likelihood of confusion as a question of pure fact subject to the clearly erroneous standard of FRCP 52(a). ${ }^{40}$ In Scandia Down Corp. v Euroquilt, Inc., the Seventh Cir-

\footnotetext{
${ }^{35}$ See Levi Strauss \& Co. $v$ Blue Bell, Inc., 778 F2d 1352, 1355-56 (9th Cir 1985) (en banc) (if likelihood of confusion is treated as a question of fact, clearly erroneous review is appropriate).

${ }^{36}$ The clearly erroneous rule does not apply if the trial judge commits an error of law. See Pullman-Standard v Swint, 456 US 273, 287 (1982). If the trial court commits legal error in a likelihood of confusion case, the appellate court will either review the record de novo, see, for example, Forum Corp. of North America v Forum, Ltd., 903 F2d 434, 438, 443 (7th Cir 1990), or will remand, see, for example, Wesco Mfg. v Tropical Attractions of Palm Beach, 833 F2d 1484, 1489 (11th Cir 1987).

${ }^{33}$ See Keds Corp. $v$ Renee International Trading Corp., 888 F2d 215, 222 (1st Cir 1989); American Home Products Corp. v Barr Laboratories, Inc., 834 F2d 368, 370 (3d Cir 1987); Pizzeria Uno v Temple, 747 F2d 1522, 1526 (4th Cir 1984); Marathon Mfg. Co. $v$ Enerlite Products Corp., 767 F2d 214, 217 (5th Cir 1985); Scandia Down, 772 F2d at 1428; Mutual of Omaha, 836 F2d at 398; Amoco Oil, 809 F2d at 661-62; Safeway Stores, Inc. $v$ Safeway Discount Drugs, Inc., 675 F2d 1160, 1164 (11th Cir 1982); Reader's Digest Association, Inc. $v$ Conservative Digest, Inc., 821 F2d 800, 804 (DC Cir 1987).

${ }^{38}$ See Levi Strauss, $778 \mathrm{~F} 2 \mathrm{~d}$ at 1355-56. See also E.\& J. Gallo Winery $v$ Gallo Cattle Co., 955 F2d 1327, 1338 (9th Cir 1992).

${ }^{30}$ See Levi Strauss, 778 F2d at $1355-56$.

to See notes 32,37 .
} 
cuit stated, as an irrefutable presumption, that likelihood of confusion is "all fact and no law," and articulated the advantages of clearly erroneous review. ${ }^{41}$ The court explained that although it could examine the marks as the lower court did, the question is whether the marks look similar to consumers, not whether the marks look similar to judges. ${ }^{42}$ Noting that the district judge had heard evidence on "how ordinary consumers perceive the marks" and reviewed evidence of actual confusion, the court concluded that de novo review of the lower court's conclusion would displace the fact finder's role. ${ }^{43}$ Similarly, the First Circuit reasoned that a finding of likelihood of confusion "quite clearly call[s] upon the [district] court's 'experience with the mainsprings of human conduct." ",44

The position adopted by these courts rests on the assumption that the trier of fact, as the decisionmaker most familiar with the evidence, is in the superior position to assess the likelihood of confusion. ${ }^{45}$ However, although this rationale supports deferential review, it fails to explain why the likelihood of confusion inquiry is "all fact and no law."

2. Justifications for applying the clearly erroneous standard.

FRCP 52(a) compels clearly erroneous review of questions of pure fact. However, one circuit that does not view likelihood of confusion as a pure question of fact has nonetheless concluded that clearly erroneous review is appropriate. In Levi Strauss \& Co. $v$ Blue Bell, Inc. ${ }^{46}$ the Ninth Circuit defined likelihood of confusion as a mixed question of fact and law. However, the court concluded that the issue is predominately one of fact, and applied the clearly erroneous standard. ${ }^{47}$ The court treated the issue as factual for review purposes because it does not implicate constitutional rights ${ }^{48}$ and "the applicable legal standard provides for a strictly factual

47 772 F2d 1423, 1428 (7th Cir 1985).

42 Id.

43 Id at 1429.

14 Keebler, 624 F2d at 377, quoting Commissioner $v$ Duberstein, 363 US 278, 289 (1960).

${ }^{45}$ Keds Corp., 888 F2d at 222; Amoco Oil, 809 F2d at 661-62; Scandia Down, 772 F2d at 1429 .

\&6 778 F2d 1352 (9th Cir 1985) (en banc).

47 Id at 1355-56. The clearly erroneous rule, however, does not apply if the district court used a incorrect legal test or misapplied the law. Clamp Mfg. Co. v Enco Mfg. Co., 870 F2d 512, 514 (9th Cir 1989).

48 See text accompanying notes 103-112. 
test." ${ }^{49}$ Further, the need for de novo review is reduced because likelihood of confusion determinations, each of which stands upon its own facts, have limited value as precedent. ${ }^{50}$ The Ninth Circuit concluded that clearly erroneous review would prevent appellate resources from being diverted to a task that properly belongs to triers of fact. ${ }^{51}$

\section{B. De Novo Review}

The Second, Sixth, and Federal Circuits review likelihood of confusion determinations in two steps. ${ }^{52}$ First, they review the findings of fact under the clearly erroneous standard. ${ }^{53}$ Second, they review de novo the legal question whether the facts as found by the lower court constitute a likelihood of confusion. ${ }^{54}$

No court has articulated a convincing justification for this two-step review. The Second Circuit's adherence to de novo review appears to be based on the belief that the appellate court is in as good a position as the trial court to determine whether likelihood of confusion exists. The Federal Circuit seemingly adopted de novo review because its predecessor, the Court of Custom and Patent Appeals (CCPA.), employed it. ${ }^{55}$ The predecessor court's only explanation for de novo review, however, was that the Trademark Trial and Appeal Board's (TTAB) determination of likelihood of confusion "is a legal conclusion" that cannot be admitted as a fact. $^{56}$

When the Sixth Circuit adopted de novo review, it said only that it agreed with the Ninth Circuit's two-level test for reviewing

$478 \mathrm{~F} 2 \mathrm{~d}$ at 1355 .

${ }^{50}$ Id at 1356 .

s2 Id at 1355 .

82 See, for example, Centaur Communications v A/S/M Communications, 830 F2d 1217, 1225 (2d Cir 1987); Wynn Oil Co. v American Way Service Corp., 943 F2d 595, 599 (6th Cir 1991) (Wynn Oil II); Electranic Design \& Sales, Inc. v Electronic Data Systems Corp., 954 F2d 713, 715 (Fed Cir 1992). The Federal Circuit employs this two-step review process when hearing appeals from the TTAB. When it hears appeals from a district court decision, it applies the review standard of the controlling circuit. See note 83 and accompanying text.

${ }_{83}$ The Second Circuit even reviews de novo the finding on the similarity of the marks because "an appellate court is in as good a position to evaluate this factor as is a trial court." Centaur Communications, 830 F2d at 1226.

s4 Wynn Oil II, 943 F2d at 599; Electronic Design, 954 F2d at 715.

- ss See Giant Food, 710 F2d at 1569 ("it is clear that our predecessor court did not apply the 'clearly erroneous' standard of review to the issue"). The decisions of the Court of Custom and Patent Appeals are binding upon the Federal Circuit. South Corp. $v$ United States, 690 F2d 1368, 1370-71 (Fed Cir 1982).

${ }_{58}$ Interstate Brands Corp. $v$ Celestial Seasonings, Inc., 576 F2d 926, 929 (CCPA 1978). 
likelihood of confusion determinations, ${ }^{57}$ an approach that the Ninth Circuit has since abandoned. ${ }^{58}$ The Ninth Circuit had reviewed likelihood of confusion determinations de novo because the determination "partakes more of the character of a conclusion of law than of a finding of fact. The inference [of likelihood of confusion is] "derived from application of a legal standard." "59 The Ninth Circuit reasoned that "[w]hen a finding is essentially one dealing with the effect of certain transactions or events, rather than a finding which resolves disputed facts, the appellate court . . . is free to draw its own conclusions," "60 because it is "in as good a position as the trial judge to determine the probability of confusion."

Although the appellate courts that employ de novo review have not explained why likelihood of confusion should be treated as a question of law, their adherence to de novo review may be based on their belief that the phrase "likely to cause confusion," presents a question of law. Because the question focuses on whether the established factual situation meets the legal standard of the likelihood of confusion, courts treat the issue as legal rather than factual.

The inquiry, however, is highly fact-specific, despite its susceptibility to characterization as a question of law. The courts' classification of the issue as a legal question might rest on the belief that a conclusion regarding the likelihood of confusion goes beyond "the application of those ordinary principles of logic and common experience." 62 The determination may be said to transcend pure fact because the legal standard dictates that courts are to consider certain factors before reaching a conclusion. ${ }^{63}$ The determination may then be said to merit plenary review because an

${ }^{87}$ Frisch's Restaurants, Inc. $v$ Elby's Big Boy, 670 F2d 642, 651 (6th Cir 1982).

${ }^{88}$ The Ninth Circuit abandoned this two-step approach after reconsidering the issue and concluding that the issue is primarily factual and that clearly erroneous review would permit better utilization of appellate resources. See text accompanying notes 46-51.

${ }^{89}$ Fleischmann, 314 F2d at 152, quoting Lundgren v Freeman, 307 F2d 104, 115 (9th Cir 1962).

Bo 314 F2d at 152 n 2, quoting Stevenot v Norberg, 210 F2d 615, 619 (9th Cir 1954).

${ }^{61} 314 \mathrm{~F} 2 \mathrm{~d}$ at 152, quoting Miles Shoes, Inc. $v$ R.H. Macy \& Co., 199 F2d 602, 602-03 (9th Cir 1952).

${ }^{82}$ Petition for a Writ of Certiorari to the U.S. Court of Appeals for the Seventh Circuit, Euroquilt, Inc. $v$ Scandia Down Corp., No 85-1038 (October Term, 1985) at 9 (on file with U Chi L Rev), citing Bose Corp. $v$ Consumers Union of United States, Inc., 466 US 485, 501 n 17 (1984).

${ }^{83}$ Id at $9-10$. 
appellate court has a responsibility to ensure that the lower court has correctly applied the legal standard.

\section{The Nature of the Conflict Between the Circuits}

This Section explains why likelihood of confusion is a mixed question of law and fact and why the federal circuit courts have been unable to agree upon the appropriate standard of review. This Section also discusses the problems that arise from the absence of a uniform review standard.

\section{A. Why Likelihood of Confusion is a Mixed Question}

In Pullman-Standard, Division of Pullman $v$ Swint, the Supreme Court distinguished between questions of pure fact and mixed questions of law and fact. ${ }^{64}$ While the Court held that appellate courts may not review questions of pure fact de novo to determine whether the facts satisfy a legal standard, the court expressly left open the question whether FRCP 52(a) compelled a similar result for mixed questions. ${ }^{65}$ The Court defined mixed questions as those inquiries "in which the historical facts are admitted or established, the rule of law is undisputed, and the issue is whether the facts satisfy the statutory standard, or to put it another way, whether the rule of law is or is not violated."

Likelihood of confusion inquiries require a court to identify facts, articulate the legal standard, and apply law to fact. ${ }^{67} \mathrm{~A}$ court must determine, based on the totality of circumstances, "whether the rule of law as applied to the established facts is or is not violated." quently unavailable, courts must infer from the facts whether "an appreciable number of ordinarily prudent purchasers are likely to be ... confused ...." Thus, the inquiry here focuses on whether the defendant's use of a mark meets this legal standard.

84 456 US 273, 279 (1982) (discriminatory intent under Title VII is a question of pure fact).

${ }^{\text {es }}$ Id at $289-90$ and $\mathrm{n} 19$.

os Id at $289 \mathrm{n} 19$.

${ }^{67}$ See United States v McConney, 728 F2d 1195, 1200 (9th Cir 1984) (en banc) (articulating three steps in deciding mixed questions of law and fact). See also Levi Strauss, 778 F2d at 1355-56 (Ninth Circuit relying on McConney in treating likelihood of confusion as a factual issue on review). See generally Henry M. Hart and Albert M. Sacks, The Legal Process: Basic Problems in Making and Application of the Law 374-76 (unpublished tentative ed 1958).

es Pullman-Standard, 456 US at $289 \mathrm{n} 19$.

${ }^{\circ}$ Perini Corp., 915 F2d at 127. 
B. Why Disagreement Exists: Problems Inherent in Determining the Appropriate Review Standard

Because likelihood of confusion is a mixed question, appellate courts find it particularly difficult to agree upon the appropriate review standard. These difficulties, inherent in the nature of mixed questions, are compounded by the problems courts have had historically in distinguishing between law and fact in trademark cases.

The Supreme Court has long recognized "the vexing nature of the distinctions between questions of fact and questions of law.""7o Although a court may avoid the dilemma of drawing a distinction between law and fact by classifying a particular determination as a mixed question, a court must still decide whether the mixed question should be treated as law or fact for review purposes. ${ }^{71}$ Established rules for making such decisions are lacking; the Court has yet to arrive at "a rule or principle that will unerringly distinguish a factual finding from a legal conclusion." 22 As a result, the decision to treat an issue as law or fact "is sometimes as much a matter of allocation of judicial resources as it is of analysis."73

In trademark law, courts have had particular difficulty in distinguishing between law and fact. ${ }^{74}$ Thus, the continuing disagreement as to whether likelihood of confusion is, or should be, treated as law or fact for review purposes is hardly surprising. Although the existence of disagreement is understandable, a uniform review standard has several advantages over the status quo.

\section{The Need for a Uniform Standard}

The absence of a uniform review standard causes a number of problems. The objective of the Lanham Act was to create a national system for the protection of trademarks against infringement. ${ }^{75}$ The existing division over the proper standard of appellate review of the key issue in trademark infringement claims undermines this objective. The outcome of an appeal can depend on what standard of review the court applies to the likelihood of con-

${ }^{70}$ Pullman-Standard, 456 US at 288.

71 Bose Corp., 466 US at 501.

72 Pullman-Standard, 456 US at 288.

${ }^{73}$ Miller v Fenton, 474 US 104, 113-14 (1985).

74 See Union National Bank, Laredo v Union National Bank, Austin, 909 F2d 839, 846 (5th Cir 1990).

75 This national system of trademark protection is to facilitate interstate commerce, prevent unfair competition, and prevent consumer fraud and deception. See 15 USC § 1127. 
fusion issue. ${ }^{76}$ Furthermore, the absence of a uniform standard creates uncertainty and confusion among practitioners and judges about the state of the law. ${ }^{77}$

Moreover, the lack of a uniform standard has encouraged forum shopping. Because the Federal Circuit has non-exclusive jurisdiction over appeals from the TTAB, a party contesting a TTAB decision may either appeal to the Federal Circuit or may file a civil action in an appropriate federal district court. However, an adverse party can prevent an appeal to the Federal Circuit by filing a civil action in a district court. ${ }^{78}$

Although these civil actions have been termed trial de novo, a district court must accept the findings of the TTAB "unless the contrary is established by testimony which in character and amount carries thorough conviction."'79 In terms of burdens of proof on an appellant, the thorough conviction standard closely resembles clearly erroneous review. ${ }^{80}$ District courts reviewing the TTAB record defer "to the lower tribunal's findings and reverse only if there is clear error in fact or error in law." Circuit, however, reviews de novo the TTAB's finding of likelihood of confusion. ${ }^{82}$

As a result, a litigant seeking reversal of a TTAB decision has a much greater burden of persuasion in a district court than in the Federal Circuit. A party who disputes the TTAB's decision may be inclined to appeal to the Federal Circuit for a de novo determination of the likelihood of confusion while the prevailing party will have a strong incentive to force dismissal of that appeal by filing a civil action in a district court (especially in a circuit that applies the clearly erroneous standard). ${ }^{\mathbf{3}}$ The divergence between the Fed-

\footnotetext{
${ }^{78}$ See, for example, Squirto o Seven-Up Co., 628 F2d 1086, 1091 (8th Cir 1980).

77 Uncertainty over the appropriate review standard can take the form of confusion within a single opinion as well as confusion within a single circuit. For example, in Life Technologies $v$ Gibbco Scientific, 826 F2d 775 (8th Cir 1987), the Eighth Circuit stated that likelihood of confusion is a question of fact subject to the clearly erroneous standard yet employed a less deferential standard to the district court's likelihood of confusion determination. Id at 776-77. Further, the Ninth Circuit adopted the clearly erroneous standard in Levi Strauss, but a panel subsequently stated that the circuit reviews the conclusion of likelihood of confusion de novo. See Miss World (UK) Ltd. v Mrs. America Pageants, Inc., 856 F2d 1445, 1448 (9th Cir 1988).

${ }^{78}$ See generally 15 USC $\S 1071$ (a), (b).

79 Morgan v Daniels, 153 US 120, 125 (1894).

so Fregeau v Mossinghoff, 776 F2d 1034, 1038 (Fed Cir 1985).

${ }^{81}$ See Electronic Design, 954 F2d at 715.

${ }^{82}$ Sarah Coventry, Inc. v T. Sardelli \& Sons, Inc., 392 F Supp 347, 354 (D RI 1975) (emphasis in original).

${ }^{83} 15$ USC \$ 1121(a) (permits appeal from district court decisions).
} 
eral Circuit's de novo approach to review of likelihood of confusion and the clearly erroneous standard the district courts and other circuits employ can thus influence litigants' forum choices. Furthermore, although the broader authority of district court review offers advantages to some parties, ${ }^{84}$ this result seems to discourage use of the Federal Circuit's special familiarity with trademark law.

\section{Why Clearly Erroneous Review Should be the Uniform STANDARD}

Although some commentators have argued that the process of determining the appropriate standard of review for a mixed question is as arbitrary as Humpty Dumpty's remark that "[ $t]$ he question is which is to be master-that's all," the process exist. This Section first argues that de novo review of likelihood of confusion determinations is not entirely consistent with Supreme Court precedent. It contends that considerations of judicial resource allocation, specified by the Supreme Court, weigh heavily for clearly erroneous review. Second, the Section offers two analogies to determinations in other areas of law that support clearly erroneous review of likelihood of confusion determinations.

\section{A. Allocational Considerations: Supreme Court Guidance}

In allocating judicial resources, the Supreme Court has looked not only at the nature of a particular inquiry, but also at the nature of the legal interests involved. ${ }^{86}$ The following subsections consider how differences in the substantive law at issue and differences in the nature and complexity of particular inquries have af-

84 A Federal Circuit decision immediately affects only the registrability of the contested mark. In a civil action in district court, however, parties may consolidate all the issues relating to the infringement. The district court not only determines the registrability of the mark, 15 USC $\S 1119$, but may also issue injunctions and award damages, costs, and attorneys' fees. 15 USC $\S \S 1114(2)(A), 1116,1117$. The efficiency benefits of permitting such consolidation were factors that motivated the adoption of the non-exclusive jurisdiction provision. See Registration of Trademarks, Joint Hearings before the Committees on Patents on S 2679, 68th Cong, 2d Sess 36-54, 76-84 (1925) (hearings on 15 USC $\$ 1071$ that indicate congressional intent with respect to consolidation of issues in the district court).

${ }^{85}$ Stephen A. Weiner, The Civil Non Jury Trial and the Law-Fact Distinction, 55 Cal L Rev 1020, 1022 n 17 (1967). Note that Humpty Dumpty's earlier statement might have been even more appropriate: "When I use a word, . . . it means just what I choose it to mean-neither more nor less." Lewis Carroll, The Annotated Alice: Alice's Adventures in Wonderland \& Through The Looking Glass 269 (C.N. Potter, 1960).

${ }^{86} \mathrm{See}$, for example, Miller, 474 US at 109-118 (voluntariness of a confession is a legal question meriting independent review in a federal habeas corpus proceeding). 
fected judgments about the appropriate allocation of appellate resources.

1. The nature of the substantive law at issue.

A comparison between Pullman-Standard and Baumgartner $v$ United States ${ }^{87}$ illustrates how differences between the rights and interests implicated by two disputes can shape the Court's determination about which standard of review, clearly erroneous or de novo, appropriately allocates judicial resources in the appellate courts. The Supreme Court's recent tendency has been to narrow the scope of appellate review where the issues do not involve fundamental constitutional rights, ${ }^{88}$ and this seems to run contrary to the continued de novo review of likelihood of confusion determinations by some circuit courts. Although de novo review of likelihood of confusion determinations does not directly conflict with any Supreme Court precedent, ${ }^{88}$ de novo review is at least inconsistent with the tenor of some of the Court's jurisprudence.

a) Pullman-Standard, Baumgartner and the Distinction Between Subsidiary and Ultimate Facts. In Pullman-Standard, the Supreme Court held that a determination of intent to discriminate in a Title VII action is a finding of fact, and that appellate courts must review all findings of fact, whether "subsidiary" or "ultimate," under the clearly erroneous rule.90 Before PullmanStandard, some appellate courts drew a distinction between subsidiary and ultimate facts when reviewing particular likelihood of confusion disputes. ${ }^{91}$ The distinction allowed an appellate court to adhere to the clearly erroneous rule in reviewing the "subsidiary" findings on each evidentiary factor, while reviewing de novo the "ultimate" determination of likelihood of confusion.92 After Pullman-Standard, however, the Third, Fourth, and Seventh Circuits

${ }^{87} 322$ US 665 (1944).

s8 See, for example, Pierce $v$ Underwood, 487 US 552 (1988) (de novo review not available on the question of whether United States' litigating position under the Equal Access to Justice Act was substantially justified); Cooter \& Gell v Hartmarx Corp., 496 US 384, 399 405 (1990) (de novo review not available on imposition of Rule 11 sanctions).

${ }^{39}$ The Court did not address in Pullman-Standard whether the clearly erroneous stan. dard of FRCP 52(a) applies to mixed questions. See Pullman-Standard, 456 US at $289 \mathrm{n} 19$.

20 456 US at 287.

01 See, for example, Scott Paper Co. v Scott's Liquid Gold, 589 F2d 1225, 1229 n 3 (3d Cir 1978).

${ }^{92}$ Pizzeria Uno Corp. $v$ Temple, 747 F2d 1522, 1526 (4th Cir 1984). 
expressly disavowed the approach. ${ }^{93}$ The Second, Sixth, and Federal Circuits' review of likelihood of confusion determinations employs a distinction nearly identical to the subsidiary/ultimate fact distinction. These circuits treat the findings on the evidentiary factors as (subsidiary) factual findings, reversible only if clearly erroneous, but they review de novo the (ultimate) determination of likelihood of confusion. These courts have been criticized for their apparent inconsistency with Pullman-Standard. ${ }^{94}$

Although courts applying de novo review to likelihood of confusion determinations have not addressed the implications of Pullman-Standard in their opinions, ${ }^{95}$ the omission might not constitute indifference to Supreme Court precedent. It might simply reflect their belief that the ultimate determination of whether confusion is likely is a conclusion of law, not governed by the clearly erroneous standard of FRCP 52(a), and therefore subject to de novo review..$^{96}$ This approach relies on distinguishing fact from law, rather than subsidiary fact from ultimate fact. The courts that still apply de novo review to likelihood of confusion findings may, therefore, read Pullman-Standard as leaving undisturbed the basis of their likelihood of confusion decisions.

Two additional lines of analysis may distinguish PullmanStandard's holding. First, one could argue that because likelihood of confusion is a mixed question, ${ }^{97}$ Pullman-Standard's reasoning does not dictate the review standard. Second, one could argue that the likelihood of confusion determination is less like Pullman-

${ }^{93}$ See American Home Products, 834 F2d at 370 n 2; Pizzeria Uno, 747 F2d at 1526; Scandia Down, 772 F2d at 1428.

94 See, for example, Scandia Down, 772 F2d at 1428 ("The Supreme Court held . . . that Rule 52(a) does not permit any distinction between ordinary and 'ultimate' findings. The Federal Circuit's cases do not discuss [Pullman-Standard v] Swint and we conclude that they are inconsistent.....").

${ }^{\text {9s }}$ See id. law.").

${ }^{96}$ Pullman-Standard, 456 US at 287 ("The Rule does not apply to conclusions of

${ }^{97}$ See text accompanying notes 64-69. The Court expressly stated that it did not address whether the clearly erroneous standard applied to mixed questions. Pullman-Standard, 456 US at $289 \mathrm{n}$ 19. The argument that Pullman-Standard does not dictate the proper standard of review for likelihood of confusion disputes has further support in the fact that Justice White authored the Court's opinion in Pullman-Standard, yet has dissented from the Court's denial of certiorari to several likelihood of confusion cases. As one cert petition pointed out, "it seems unlikely that Justice White would prescribe the remedy of court intervention for a self-healing conflict." Reply Brief in Support of Petition for a Writ of Certiorari to the U.S. Court of Appeals for the Seventh Circuit, Euroquilt, Inc. $v$ Scandia Down Corp., No 85-1038 (October Term, 1985) at 2 (on file with U Chi L Rev). 
Standard than the distinction between subsidiary and ultimate facts the Court recognized in Baumgartner $v$ United States.

In Baumgartner, the issue was whether the lower court's findings constituted the clear and convincing proof of fraud necessary to justify a denaturalization decree. The Court treated the trial court's finding that this standard of proof had been met as a finding of ultimate fact. ${ }^{98}$ When a court decides an ultimate fact, its conclusion may be drawn from "the whole mass of evidence." cause such conclusions may rest on the court's assessment of "fallible evidence," the Court explained, a reviewing court may need to appraise the strength of the entire body of evidence independently in order to ensure the validity of the lower court's finding. ${ }^{100}$ Pullman-Standard distinguished this finding by reasoning that the question whether the denaturalization decree was justified, unlike the intent issue in a Title VII case, was not a pure finding of fact but a finding that "clearly impl[ied] the application of standards of law." 10x

At first glance, Baumgartner's analysis provides support for the Second, Sixth, and Federal Circuits' two-step approach to likelihood of confusion inquiries because the two approaches appear quite similar. ${ }^{102}$ For example, to determine whether confusion is likely, a court must assess the entire body of evidence. However, although Baumgartner is still good law after Pullman-Standard, Baumgartner's context indicates that its reasoning should not be construed to support de novo review of likelihood of confusion determinations.

b) The Court's recent limitations on the use of de novo review. In Baumgartner, the Court appears to have justified de novo review on the ground that "the decision [at issue]. . . cannot escape [] social judgments." 103 The Court implied that because denaturalization decisions lie "close to opinions regarding the whole nature of our Government and the duties and immunities of citi-

${ }^{98} 322$ US at 670-71.

${ }^{98}$ Id at 671 .

${ }^{100}$ Id at $670-71$.

101456 US at $287 \mathrm{n} 16$, citing Baumgartner, 322 US at 671.

${ }^{102}$ One commentator has suggested that, given the similarities between the two approaches, disapproval of the minority circuit's approach would require the explicit disavowal of Baumgartner's reasoning. See Comment, Appellate Review of Lanham Act Violations: Is Likelihood of Confusion a Question of Law or Fact?, 38 Sw L J 743, 766-67 (1984).

${ }^{103} 322$ US at 671. 
zenship,"104 they necessitate the thorough inquiry independent appellate review affords. Denaturalization decisions implicate important social judgments and have the potential to deny constitutional rights, privileges, and immunities. The Court deemed de novo necessary to ensure just decisions and protect fundamental liberties. ${ }^{105}$

As Baumgartner implied and subsequent Court precedent indicates, the need for de novo review "varies according to the nature of the substantive law at issue."108 Fact-specific determinations implicating fundamental constitutional liberties are likely to warrant de novo review. ${ }^{107}$ For example, in Ker $v$ California, the Court stated that reasonableness determinations under the Fourth Amendment receive de novo review even though such determinations rest on the facts and circumstances of each case. ${ }^{108}$ On review the mixed question of probable cause is treated, therefore, as a question of law. Similarly, in Bose Corp. $v$ Consumers Union of United States, Inc., the Court held that appellate courts should review de novo, as a question of law, proof of actual malice in a libel case-despite such fact-specific issues as the scienter element. ${ }^{108}$

When a case implicates a constitutional right, the application of law to fact often requires a court to consider the law regarding the relevant constitutional provision. In both $K e r$ and Bose, for example, the holdings implicitly recognized that the inquiries involved in applying the legal standards-probable cause and actual malice-go beyond the facts and require the court to consider abstract legal principles that inform constitutional jurisprudence. ${ }^{110}$ The need for de novo review, therefore, increases where constitutional rights are involved. The Court emphasized in both cases the appellate court's duty to review independently the record in matters involving fundamental constitutional rights to ensure that the lower courts' decisions are consistent with principles of constitutional law and do not infringe upon fundamental liberties. ${ }^{111}$

A similar constitutionally-based interest in independent review of likelihood of confusion determinations does not exist in

106 Id.

105 See Bose, 466 US at 510-11.

${ }^{108}$ Id at $501 \mathrm{n} 17$.

${ }^{107}$ Baumgartner, 322 US at 671. See also Bose, 466 US at 510-11.

${ }_{108} 374$ US 23, 33-34 (1963).

108466 US 485, 510-11 (1984) (libel implicates the First Amendment).

110 See McConney, 728 F2d at 1203.

11 See Ker, 374 US at 33-34; Bose, 466 US at 499-511. See also New York Times Co. $v$ Sullivan, 376 US 254, 284-86 (1964). 
trademark law. Supreme Court cases involving trademark law have not indicated that the interests implicated warrant de novo review. ${ }^{112}$ Because fundamental constitutional liberties are not at stake in trademark disputes, appellate courts lack justification for de novo review of likelihood of confusion determinations. Although Pullman-Standard does not preclude the continued de novo review of likelihood of confusion determinations, the de novo approach here ignores the lesson implied by a comparison of Pullman-Standard and Baumgartner and its successors: de novo review of fact-specific inquiries is necessary only when the case implicates fundamental constitutional rights or consequential social values.

2. Considerations of the nature and complexity of the inquiry in allocating judicial resources.

Although the practices of some circuits indicate that courts can independently evaluate issues relevant to likelihood of confusion, this independent evaluation does not establish that de novo review promotes judicial accuracy or the efficient use of appellate resources. In Salve Regina College $v$ Russell, ${ }^{113}$ a recent standard of review decision, the Supreme Court discussed the advantages of de novo review and the types of inquiries that warrant it. The Court stated that independent appellate review of legal issues serves two policy goals: doctrinal coherence and economy of judicial administration. ${ }^{114}$ The Court explained that the logistical burdens of trial advocacy frequently limit the extent to which trial counsel can supplement the district court's legal research with memoranda and briefs. As a result, "trial judges often must resolve complicated legal questions without benefit of 'extended reflection [or] extensive information." "115 The Court stated that deferential review of mixed questions is warranted when it appears that the district court is in a better position to determine the issue than the appellate court and "probing appellate scrutiny will not contribute to the clarity of legal doctrine."116

\footnotetext{
112 See, for example, Inwood Laboratories, Inc. v Ives Laboratories, Inc., 456 US 844, 855 (1982) (findings underlying the district court's determination that manufacturers of a generic drug could not be held liable for trademark infringement by pharmacists who mislabeled the generic drug with a competitor's registered trademark were not clearly erroneous). ${ }^{113} 111$ S Ct 1217, 1221 (1991) (de novo review of federal district court interpretations of state law questions is appropriate).

$114 \mathrm{Id}$.

115 Id.

118 Id at 1222.
} 
Unlike the matter at issue in Salve Regina College, the interpretation of state law by federal courts, trademark infringement suits do not require resolution of complex legal questions. "Reflective dialogue and collective judgment"117 are not necessary to determine the state of the law concerning likelihood of confusion. Rather, the legal standard is well defined and the trial court must apply the facts to that existing legal standard. Further, because trademark cases usually involve sophisticated parties (who are more likely to employ sophisticated attorneys), the trial briefs and memoranda will more likely provide sufficient guidance to a trial judge unfamiliar with trademark law.

To reduce the risk of judicial error, the court in the superior position to evaluate and weigh the evidence should have the primary responsibility for resolving predominately fact-based disputes. ${ }^{118}$ As the trier of fact, the district court or the TTAB is in the superior position. Clearly erroneous review would help conserve appellate resources for issues that the appellate courts are better situated to decide. The need for de novo review of likelihood of confusion determinations is further reduced because these determinations have little significance beyond the immediate dispute. Appellate resources should not, therefore, be allocated to the reexamination of fact-specific issues that can be determined with the same, or nearly the same, degree of consistency at the trial level. ${ }^{119}$

\section{B. Analogous Determinations in Other Areas of Law}

Analogies to similar inquiries in other areas of the law are useful in determining whether a particular mixed question should be treated as fact or law for review purposes. This Section analogizes the likelihood of confusion determination to both the reasonable royalty standard for damage award determinations in patent infringement cases and the negligence determination in tort actions. Because courts accord clearly erroneous review to both of these determinations, courts should likewise review likelihood of confusion as a factual issue subject to the clearly erroneous standard.

117 Id at 1221.

${ }_{118}$ Zenith Radio Corp. v Hazeltine Research, Inc., 395 US 100, 123 (1969).

11 Anderson $v$ Bessemer City, 470 US 564, 574-75 (1985) (appellate courts must defer to trial court's finding's based on documentary evidence and on inferences drawn from other facts). As the Court stated in Miller $v$ Fenton: "[various] considerations often suggest the appropriateness of resolving close questions concerning the status of an issue as one of 'law' or 'fact' in favor of extending deference to the trial court." 474 US 104, 114 (1985). 
1. The reasonable royalty standard.

Both the likelihood of confusion determination in trademark law and the reasonable royalty rule in patent law protect intellectual property rights. Trademark law and patent law grant exclusive use of intangible property and protect that property against misappropriation. Both trademark and patent infringement are commercial torts. ${ }^{120}$

The reasonable royalty standard is a means to determine damages in patent infringement cases when actual damages, such as lost profits, cannot be determined. ${ }^{121} \mathrm{~A}$ reasonable royalty is an amount that a person who wants to manufacture and sell a patented article for a profit would be willing to pay as a royalty. ${ }^{122}$ As in likelihood of confusion determinations, the reasonable royalty determination is based on a legal fiction. ${ }^{123}$ In likelihood of confusion determinations, the legal fiction is a hypothetical consumer, the "ordinarily prudent purchaser." In reasonable royalty determinations, the legal fiction consists of two hypothetical parties negotiating a royalty. The parties are assumed to be reasonable businesspersons willing to enter into a licensing agreement. To establish the damage award, the court determines the rate that a willing licensor and a willing licensee would have negotiated at the time of the first infringement. ${ }^{124}$

Because the likelihood of confusion determination depends on the general impression of the average consumer, rather than a sideby-side comparison of the marks, the trier of fact needs to consider and weigh various evidentiary factors to determine how the average consumer would perceive and recollect the marks. Similarly, in reasonable royalty determinations, courts will consider a number of different evidentiary factors depending on the circumstances of the infringement. ${ }^{125}$ Using the willing licensor-willing licensee construct, a court weighs and balances findings from these factors to determine the appropriate damage amount. The legal fiction rests on the assumption that the parties are prudent businesspersons

${ }^{120}$ Railex Corp. $v$ Joseph Guss \& Sons, Inc., 40 FRD 119, 124-25 (D DC 1966).

${ }^{121}$ See Panduit Corp. v Stahlin Bros. Fibre Works, Inc., 575 F2d 1152, 1157, 1157 n 1 (6th Cir 1978), citing 35 USC $\S 284$.

${ }^{122}$ Id at $1157-58$.

123 Id at 1159.

124 Stickle v Heublein, Inc., 716 F2d 1550, 1561 (Fed Cir 1983).

128 The factors relevant to the hypothetical negotiation were articulated in GeorgiaPacific Corp. v United States Plywood Corp., 318 F Supp 1116, 1120 (S D NY 1970). See also Panduit Corp., 575 F2d at 1162. 
who would reach a royalty reasonable to both;126 that is, the determination is based on the interests of the hypothetical parties, rather than what the court perceives as just.

The similarity of the evidentiary factors used in making the two determinations suggests the similarity of the two inquiries. The nature of the patented invention and the distinctiveness of a mark are significant, ${ }^{127}$ as is the extent to which the plaintiff has used the mark or the device. ${ }^{128} \mathrm{~A}$ court in a patent case may look at the extent to which the licensor has a policy to maintain the patent monopoly. ${ }^{128}$ Similarly, a court in a trademark case looks at whether a senior user has actively protected its interests in the mark. ${ }^{130}$ In both instances, courts consider whether the senior user or the licensor monitors the trade and enforces his or her interests against apparent infringers. Finally, in both inquiries, a court may consider the extent to which the parties compete with one another ${ }^{131}$ and the infringer's intent. ${ }^{132}$

In addition to being structurally and substantively similar, the two inquiries share functional similarities. Both determinations require a court to make a highly fact-specific inquiry based on the relevant evidentiary factors. ${ }^{133}$ Further, both determinations frequently require courts to evaluate conflicting testimonial and documentary evidence on disputed issues and make credibility determinations. ${ }^{134}$ To reach conclusions, courts must exercise their discretion and weigh the evidentiary factors in a manner consistent with the controlling legal fiction and the circumstances of the case.

${ }^{128}$ Panduit Corp., 575 F2d at 1158-59.

${ }_{127}$ Miss World (UK) Ltd. v Mrs. America Pageants, Inc., 856 F2d 1445, 1448-50 (9th Cir 1988) (trademark); Polaroid Corp. v Eastman Kodak Co., 16 USPQ2d 1481, 1490-91 (D Mass 1990) (patent).

${ }^{128}$ Keds Corp. $v$ Renee International Trading Corp., 888 F2d 215, 222 (1st Cir 1989) (trademark); Ziggity Systems, Inc. v Val Watering Systems, 769 F Supp 752, 827 (E D Pa 1990) (patent). 1992).

128 Andrew Corp. $v$ Gabriel Electronics, 1992 US Dist LEXIS 2701, *30 (D Maine

${ }^{130}$ Plus Products v Plus Discount Foods, Inc., 722 F2d 999, 1002 (2d Cir 1983).

131 General Mills, Inc. v Kellogg Co., 824 F2d 622, 627-28 (8th Cir 1987) (trademark); Rite-Hite Corp. v Kelley Co., Inc., 774 F Supp 1514, 1543 (E D Wis 1991) (patent).

${ }^{132}$ Century 21 Real Estate Corp $v$ Sandlin, 846 F2d 1175, 1179-80 (9th Cir 1988) (trademark); Fromson $v$ Western Litho Plate and Supply Co., 13 USPQ2d 1856, 1861-62 (E D Mo 1989) (patent).

${ }^{133}$ Eclipse Associates Ltd. v Data General Corp., 894 F2d 1114, 1116-18 (9th Cir 1990) (trademark); Panduit Corp., 575 F2d at 1159 (patent); American Original Corp. $v$ Jenkins Food Corp., 774 F2d 459, 462-63 (Fed Cir 1985) (patent).

134 Scandia Down, 772 F2d at 1428-31 (trademark); American Original, 774 F2d at 462, 464 (patent). 
Both determinations depend more on the facts and circumstances of each specific case than on a legal standard. ${ }^{335}$

Damage awards based on reasonable royalty determinations are reviewed as findings of fact under the clearly erroneous standard. ${ }^{136}$ From functional and allocational perspectives, it would be consistent for appellate courts also to adhere to the clearly erroneous standard when reviewing lower court determinations of likelihood of confusion, thus deferring to the trier of fact, the decisionmaker most familiar with a case's facts and circumstances.

\section{Negligence.}

Negligence and likelihood of confusion are both standards for determining liability. Liability rests on conduct that unreasonably interferes with the interests of others. In negligence, a party breaches a duty of reasonable care. In trademark infringement, a party breaches a duty not to cause or create consumer confusion. In both determinations, a court's conclusion rests on a legal fiction.

In both negligence and trademark infringement, the wide variety of potential situations makes it difficult, if not impossible, to develop specific standards or rules in advance for all situations. As a result, the trier of fact applies a reasonable person standard, based on a person of ordinary skills using ordinary care. In likelihood of confusion disputes, the issue is whether the allegedly infringing mark will confuse "an appreciable number of ordinarily prudent purchasers." ${ }^{37}$ In negligence determinations, the question is what an ordinary but prudent person would think it reasonable to do under the circumstances of the case. ${ }^{138}$ In both determinations, the legal standard is fact-specific; the court's final conclusion in negligence cases depends on the facts of the case, construed in accordance with the reasonable person standard.

As in the likelihood of confusion inquiry, the negligence inquiry presents a mixed question whose resolution requires fact identification, law declaration, and law application. ${ }^{139}$ Negligence determinations require a court to articulate the standard of care against which the defendant's conduct must be measured and to

135 Panduit Corp., 575 F2d at 1159 ("The amount of a reasonable royalty after infringement turns on the facts of each case, as best they may be determined.").

${ }^{136}$ Smithkline Diagnostics, Inc. v Helena Laboratories Corp., 926 F2d 1161, 1164 n 2 (Fed Cir 1991).

${ }^{137}$ Perini Corp., 915 F2d at 127.

${ }^{138}$ Deguio v U.S., 920 F2d 103, 105-06 (1st Cir 1990).

130 McConney, 728 F2d at 1200. 
apply that standard of care to evidentiary fact-findings. The standard of care is the legal standard in the case and defines what obligations exist between the parties. Most frequently, the applicable standard is a duty of reasonable care as defined by community norms. ${ }^{140}$ Because the legal standard is based on "data of practical human experience," the trial court's findings of evidentiary fact effectively determine the negligence question. ${ }^{141}$

Negligence is a mixed question of law and fact ${ }^{142}$ and all federal courts of appeal, except the Second Circuit, treat it as a question of fact subject to clearly erroneous review. ${ }^{143}$ Clearly erroneous review of negligence determinations is consistent with the deferential review standard the Supreme Court has accorded to other mixed questions that do not implicate fundamental constitutional rights or significant social judgments, determinations in which reasonableness plays a significant role. ${ }^{144}$

The justification for clearly erroneous review in likelihood of confusion cases transcends the justification for this standard in cases of negligence. The legal standard used in negligence determinations is more amorphous than the legal standard in likelihood of confusion cases. Negligence determinations rest on the reasonable person construct alone, rather than, as in likelihood of confusion inquiries, on the reasonable person construct and articulated evidentiary factors. The legal standard in negligence cases provides little specific guidance as to what is reasonable. The meaning of the standard, therefore, can vary greatly because a variety of judgments as to what is reasonable are socially acceptable. As an allocational matter, if the clearly erroneous standard governs the review of negligence determinations, the standard should also govern likelihood of confusion determinations, where the applicable legal standard is less ambiguous.

140 McConney, $728 \mathrm{~F} 2 \mathrm{~d}$ at 1204.

141 Id.

${ }_{142}$ Barnett v Sea Land Service, Inc., 875 F2d 741, 745 (9th Cir 1989).

${ }^{143}$ See James Wm. Moore and Jo Desha Lucas, 5A Moore's Federal Practice II 52.05[1], 52-102 (Bender, 2d ed 1992). The Second Circuit reviews negligence determinations de novo because it believes that the only way a reviewing court can determine whether the standard of care has been formulated correctly is to review freely the application of the legal standard to the established facts. Mamiye Bros. $v$ Barber S.S. Lines, Inc., 360 F2d 774, 776-78 (2d Cir 1966).

164 See, for example, Cooter \& Gell, 496 US at 405 (appellate courts should employ an abuse of discretion standard when reviewing all aspects of a district court's decision in a Rule 11 proceeding because the legal standard is highly fact-dependent). 


\section{ConCLUSION}

Determinations of likelihood of confusion in trademark cases are predominately factual in nature and well suited to clearly erroneous review. Treating likelihood of confusion as a question of fact for review purposes accords with the Supreme Court's standard of review jurisprudence and is supported by analogous determinations in other areas of law. As the Court stated in a case involving contributory trademark infringement, the clearly erroneous standard of FRCP 52(a) "recognizes and rests upon the unique opportunity afforded the trial judge to evaluate the credibility of witnesses and to weigh the evidence."145 The trier of fact, as the decisionmaker most familiar with the circumstances and the facts of an alleged trademark infringement, is better positioned than the appellate court to determine whether an infringement has occurred under a likelihood of confusion theory. An appellate court should defer to the fact finder's judgments on this issue unless, after considering all the evidence, the court is "left with the definite and firm conviction that a mistake has been committed." 146 In the interests of doctrinal coherence, judicial accuracy and efficiency, and the prevention of forum shopping, the clearly erroneous rule should become the uniform standard for reviewing likelihood of confusion determinations.

${ }^{245}$ Inwood Laboratories, 456 US at 855.

1* United States v U.S. Gypsum Co., 333 US 364, 395 (1948). See also Anderson, 470 US at 573. If, however, the lower court applied an incorrect or incomplete test to determine likelihood of confusion, the lower court's fact findings and determination of likelihood of confusion should lose the shield of the clearly erroneous standard, and the determination of likelihood of confusion, depending on the facts and circumstances of the case, should be reviewed de novo or remanded. 
. 